\title{
Ion mobility spectrometry: the diagnostic tool of third millennium medicine
}

\section{SUMMARY}

Ion mobility spectrometry (IMS) is a fast, low cost, portable, and sensitive technique that separates ions in a drift tube under the influence of an electric field according to their size and shape. IMS represents a non-invasive and reliable instrumental alternative for the diagnosis of different diseases through the analysis of volatile metabolites in biological samples. IMS has applications in medicine in the study of volatile compounds for the non-invasive diagnose of bronchial carcinoma, chronic obstructive pulmonary disease, and other diseases analysing breath, urine, blood, faeces, and other biological samples. This technique has been used to study complex mixtures such as proteomes, metabolomes, complete organisms like bacteria and viruses, monitor anaesthetic agents, determine drugs, pharmaceuticals, and volatile compounds in human body fluids, and others. Pharmaceutical applications include analysis of over-thecounter-drugs, quality assessment, and cleaning verification. Medical practice needs non-invasive, robust, secure, fast, real-time, and low-cost methods with high sensitivity and compact size instruments to diagnose different diseases and IMS is the diagnostic tool that meets all these requirements of the Medicine of the future.

KEYWORDS: Ion mobility spectrometry. Breath tests. Lung diseases. Carcinoma, bronchogenic.

\section{INTRODUCTION}

Ion mobility spectrometry (IMS) is an atmospheric pressure method that separates ions in the gas phase. IMS is relatively inexpensive, fast, robust, and easy to use. This analytical technique is sensitive to ions of organic or inorganic compounds, and can detect elements, particles and whole organisms from volatile metabolites in-situ. IMS is especially sensitive to heteroatoms and organic compounds and can be the method of choice to quickly diagnose different diseases in the emergency room.

\section{INSTRUMENTAL}

In IMS, compounds are ionized and accelerated by an electric field in a drift tube and move against a counter-flow of neutral drift gas (air or nitrogen) introduced in the end of the tube (Figure 1). The ions collide continuously against the drift gas, which decelerates them in their way to the detector according to their size and shape; the arrival time at the detector, which depends on the ion's size and shape, allows the ion identification. ${ }^{1}$ 


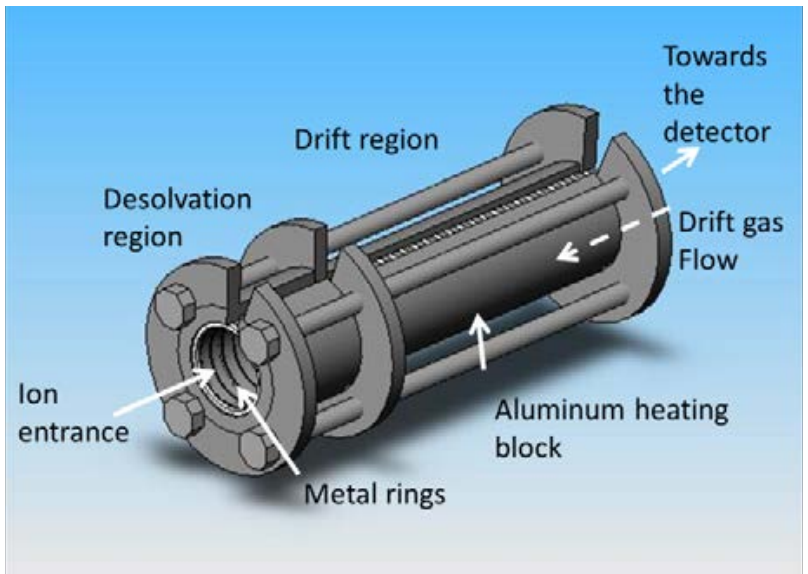

FIGURE 1. Ion mobility spectrometer

Clinical Practice requires fast, safe, low cost, real-time, and non-invasive methods to diagnose different diseases. IMS supplies information on human health through the analysis of volatile organic compounds (VOCs) from exhaled breath, urine, faeces, and other biological samples with all the above requirements for Clinical Practice.

\section{BREATH DIAGNOSIS}

Instrumental breath diagnosis is a new area of research with a promising clinical potential with fast real-time analysis of metabolites in exhaled breath. The method is based on the detection of natural volatile metabolites in breath, in healthy states or from diseases, and metabolites from contamination or produced by microbiota in the respiratory system. IMS provides insight on perturbations of the human exposome through breath measurements that can be interpreted as preclinical signals of adverse outcome pathways. Oxidative stress status may be monitored via volatile products of lipid peroxidation, and phenotypic information, important in personalized medicine, is obtained from the measurement of the activity of enzymes such as dihydropyrimidine dehydrogenase. ${ }^{2}$ Asthma, bronchial carcinoma, chronic obstructive pulmonary disease, inflammatory lung disease, or metabolic disorders are diseases that may be diagnosed now or in the near future using instrumental breath diagnosis. Vautz et al. ${ }^{3}$ coupled IMS to multi-capillary columns (IMS-MCC) for the selective characterization of human breath for early diagnosis as well as medication and therapy control. They demonstrated the complete procedure of breath analyses including the evaluation and interpretation of the data obtained after eating. The signals were compared to a compound database for identification. Hauschild et al. ${ }^{4}$ highlighted that the potential of this methodology depends on the successful application of computational approaches for finding relevant VOCs and consequent classification of patients into disease-specific profile groups.

Breath diagnosis includes the detection of drugs, ${ }^{5}$ metabolites and volatile organic compounds in the breath of patients as a potential diagnostic tool for chronic obstructive pulmonary disease, ${ }^{6}$ bronchial carcinoma, ${ }^{7}$ renal failure ${ }^{8}{ }^{8}$ colorectal cancer, ${ }^{9,10}$ non-alcoholic fatty liver disease ${ }^{11}$ and other diseases ${ }^{12}$ and conditions such as gut dysbiosis. ${ }^{13}$ Additionally, there are promising results in the determination of asbestos-related diseases. ${ }^{14}$ Breath analysis was able to identify unique VOCs profiles in patient groups; in 79 volunteers, 1179 different VOCs were detected of which thirteen were sufficient to correctly classify all 79 subjects. ${ }^{15}$

Methodological issues have been detected in breath measurements procedures. Bunkowski et al. ${ }^{16}$ studied the variations of eight different compounds over a time period of 11 months in the exhaled breath of the same person in the same room environment and showed that the room air concentration of VOCs must be taken into account to measure the individual variability for medical questions.

\section{Applications of Breath diagnosis in Medicine}

Numerous diseases can be determined by the fingerprint of VOCs from breath, urine or faeces. These include sleep apnoea syndrome, ${ }^{17}$ renal failure, sarcoidosis, chronic obstructive pulmonary disease, cancer, cystic fibrosis and more.

Pagonas et al. ${ }^{8}$ studied breath using IMS and found significant differences in the spectra of 28 patients with or without renal failure. They evaluated 13 compounds that accumulated with decreasing renal function and concluded that impairment of renal function induces a characteristic fingerprint of volatile compounds in breath that can be used for diagnosis. Similar results were obtained by Jazan and Mirzaei. $^{18}$

Sarcoidosis is an inflammatory disease that usually begins with lung inflammation that spreads to other organs, and immune-system cells forming nodes (granulomas) in various organs affecting their function (Figure 2). In one investigation, breath sam- 


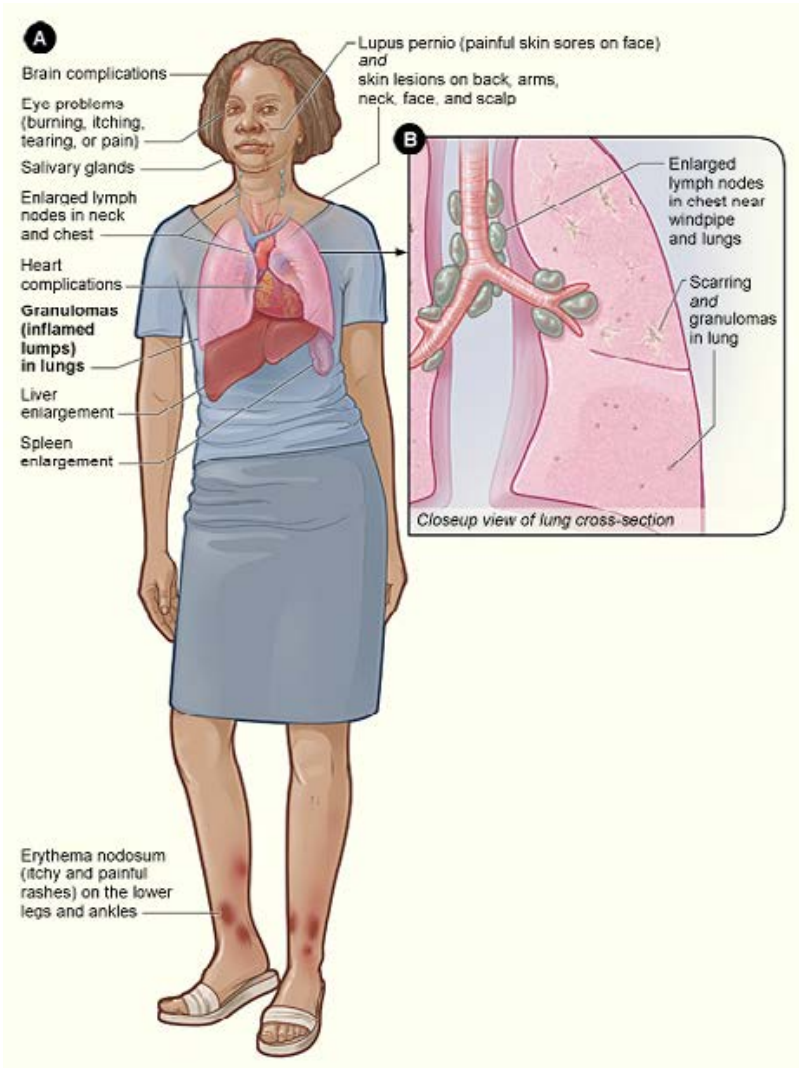

FIGURE 2. Sarcoidosis. From USA National Heart, Lung, and Blood Institute: Lung Diseases: Sarcoidosis: Signs \& Symptoms. https://www.nhlbi.nih.gov/health-topics/sarcoidosis

ples of nine patients with sarcoidosis and suspicion of sarcoidosis, due to mediastinal lymph node enlargement, were investigated by IMS-MCC. Patients with sarcoidosis showed a highly congruent distribution of metabolites in exhaled air, which was different from patients with unspecific mediastinal lymph node enlargement. ${ }^{19}$ In another study, IMS-MCC was also used to differentiate these patients by monitoring a single biomarker in breath. ${ }^{20}$

Chronic obstructive pulmonary disease (COPD) is an inflammatory condition characterized by oxidative stress and particular VOCs from lungs (Figure 3). ${ }^{6}$ Hauschild et al. ${ }^{4}$ analysed breath data by IMSMCC from 84 volunteers, either healthy or suffering from COPD or bronchial carcinoma and extracted 28-scoring VOCs that allowed differentiating COPD patients. On the other hand, Basanta et al. ${ }^{21}$ used differential mobility spectrometry (DMS) to discriminate between individuals with and without COPD. Using gas chromatography-IMS, Allers et al. ${ }^{22}$ found three VOCs showing a significant difference between healthy controls and patients with COPD indicating the IMS potential for early detection and differentiation of COPD.

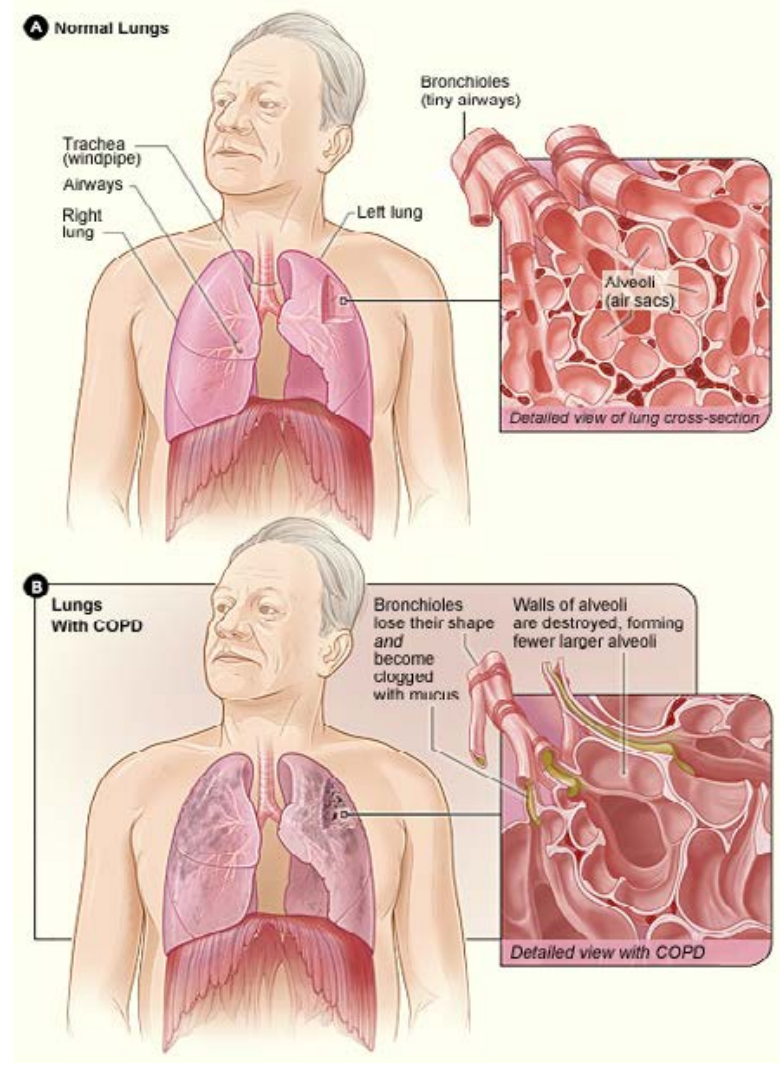

FIGURE 3. Chronic obstructive pulmonary disease (COPD). From USA National Heart Lung and Blood Institute. https:// www.nhlbi.nih.gov/health-topics/copd

Carbonyls compounds have been defined as cancer markers with significantly higher concentrations in patients with lung cancer distinguishing benign disease from both early and III and IV stages. ${ }^{23,24}$ Westhoff et al. ${ }^{25}$ used IMS-MCC to study volatile metabolites in human breath of patients with lung cancer. They found typical spectra of patients with lung cancer different from those of the control group demonstrating the usefulness of IMS in medical diagnosis. Analytical methods based on exhaled breath for early detection of lung cancer have been reviewed. ${ }^{26}$

Cystic fibrosis (CF) is an autosomal disorder that thickens mucus clogging lungs, and producing respiratory complications, facilitating the growth of bacteria (Figure 4). CF breath metabolomics investigations using exhaled breath condensate can expose CF metabolic alterations and aid in assessing CF therapies. Traveling wave IMS coupled with mass spectrometry was used to profile metabolites in breath condensates, finding that a panel of three metabolites differentiated between healthy controls and CF patients with excellent cross-validated accuracy. ${ }^{27}$

A comprehensive database of IMS medical appli- 
cations has been presented, which combines metabolic maps with heterogeneous biomedical data. The database is a flexible centralized data repository capable of gathering all kinds of information related to the composition of human breath; the platform will support biomarker identification and validation based on IMS-MCC. ${ }^{28}$

\section{APPLICATIONS OF IMS DIAGNOSIS WITH OTHER CLINICAL SAMPLES}

Bile acid diarrhoea, inflammatory bowel disease, and renal, liver, and neurodegenerative diseases have been studied with IMS in other biological samples different to breath and the potential of IMS to diagnose these diseases has been shown. An illustration of this potential for disease characterization was an application of IMS-MS analysing blood serum from 60 post-liver transplant patients with recurrent fibrosis progression and 60 non-transplant patients. Significant differential abundances were found in 136 proteins in the serum of transplant patients. Of these, 112 proteins were observed to discriminate between non-progressors (NP) and fast progressors, and 101 between NP and SP (slow progressors) patient groups, with 77 overlapping. ${ }^{29}$

Changes in gut microbiota that affect the health of the intestines and metabolic profile can be determined by IMS or by genomic or faecal analysis. The last ones are too expensive, slow or cumbersome for daily medical practice. The pathogenesis of inflammatory bowel disease (IBD) involves bacterial polysaccharide fermentation producing a fermentation profile traced in urine with electronic nose and Field Asymmetric Ion Mobility Spectrometry (FAIMS). ${ }^{30}$ Using FAIMS, Arasaradnam et al..$^{31}$ distinguished between complete versus partial bowel cleansing studying the changes in the patient's fermentone and tracked evolving bacterial recolonization. ${ }^{32}$ Patients undergoing pelvic radiotherapy often suffer from gastrointestinal side-effects due to products of fermentation caused by gut microflora that can be detected by IMS. Covington et al. ${ }^{33}$ investigated electronic nose and FAIMS to identify patients after treatment by their toxicity through IMS

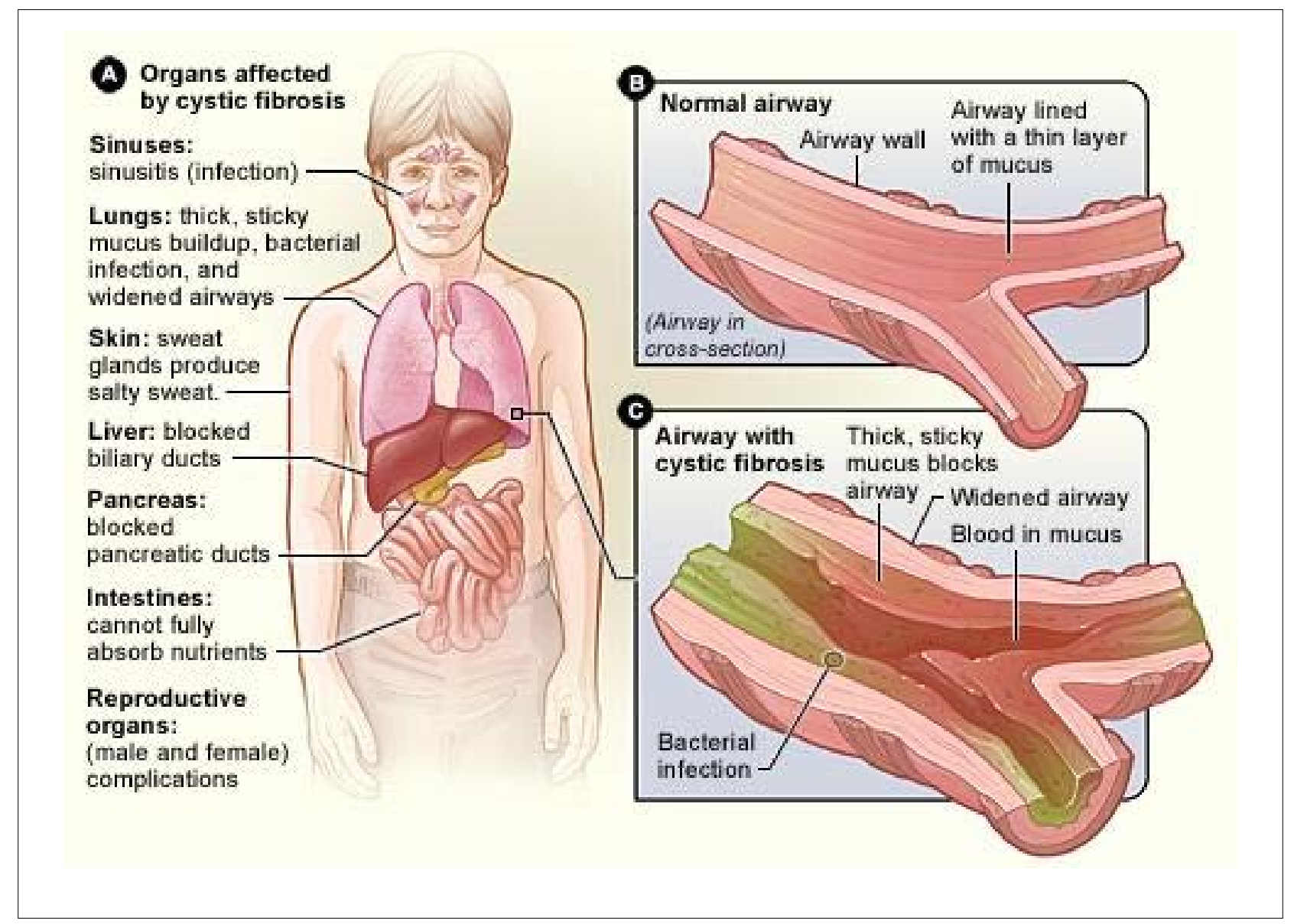

FIGURE 4. Cystic fibrosis. From USA National Heart Lung and Blood Institute. https://www.nhlbi.nih.gov/health-topics/ cystic-fibrosis 
faecal analysis and informed the treatment pathway for this disease.

Bile acid diarrhoea (BAD) is a gastrointestinal disease diagnosed through imaging techniques. VOCs in urine from patients with BAD and ulcerative colitis were determined in a study. Patients with BAD had 2-propanol and acetamide not present or reduced in ulcerative colitis and control samples. Statistical differences were found between BAD vs. ulcerative colitis and healthy controls. ${ }^{34}$ The results indicate the potential of FAIMS for the diagnosis of BAD.

Altered branching and aberrant expression of $\mathrm{N}$-linked glycan are known to be associated with disease states such as cancer. Isailovic et al..$^{35}$ examined IMS-MS for characterizing serum N-linked glycan from 81 volunteers, 28 with cirrhosis of the liver, 25 with liver cancer, and 28 apparently healthy. IMS-MS and principal component analysis of the IMS profiles differentiated the liver cancer group from the other samples. ${ }^{36}$

IMS has the potential for the study of neurodegenerative diseases. Zhang et al. ${ }^{37}$, studied the striatal metabolomes in a Parkinson's like disease rat model and found metabolic differences with samples and healthy controls using principal component analysis. Intermediate assemblies of amyloid cascades that yield peptide $\beta$-sheet fibrils and plaques have been recognized as mediators of neurodegenerative diseases. Bleiholder et al..$^{38}$ used IMS to deduce the modulation of peptide self-assembly pathways in the amyloid- $\beta$ protein fragment $A \beta(25-35)$ by two amyloid inhibitors currently in clinical trials for Alzheimer's Disease. They also demonstrated that IMSMS can guide the development of therapeutic agents and drug evaluation for these processes. The study of amyloid formation using IMS-MS has led to an enhanced understanding of the mechanism by which small molecules modulate amyloid formation. ${ }^{39}$

IMS has also been applied to the determination of different compounds of medical interest in several body fluids. ${ }^{5}$ Bocos-Bintintan et al..$^{40}$ developed a fast quantitative assay to characterize methanol in human saliva by gas chromatography-DMS in less than three minutes from 25 to $500 \mathrm{mg} \mathrm{L}^{-1}$. Eiceman et al. ${ }^{41}$, proposed an alternative simple and cost-effective aspiration condenser to existing anaesthesia monitoring technologies. Common volatile anaesthetic agents (halothane, isoflurane, and enflurane) showed an identification accuracy of $98 \%$ at concentrations higher than $1.0 \%$.

\section{Potential medical applications of IMS}

One possible application of IMS breath analysis may be the monitoring of metabolic control in patients with diabetes mellitus (Figure 5). Several studies have been performed trying to relate VOCs in breath with diabetes mellitus. Galassetti et al. ${ }^{42}$ found that breath ethanol and acetone would provide a good approximation of the blood glucose profile during a glucose load. Smith et al. ${ }^{43}$ reviewed the studies of breath analysis in diabetes, focusing on breath metabolites altered in this disease, highlighting the factors that confound interpretation. They conclude that further work is required in terms of the clinical and analytical validation and which breath metabolites should be monitored. A more recent review on this issue states that it is too early to draw a general conclusion on the relationship between breath acetone and blood glucose from the very limited data in the literature. ${ }^{44}$

The usefulness for the diagnosis of bacterial infections by IMS has been indicated by the determination of bacteria by enzyme-substrate reactions that can have numerous applications in medicine. In a method, o-nitrophenyl-galactopyranoside was introduced in solutions contaminated with bacteria or in cell cultures and bacteria produced o-nitrophenol, detected by IMS. ${ }^{45}$ DMS was used for sampling gases produced by bacteria cultures; pattern discovery/

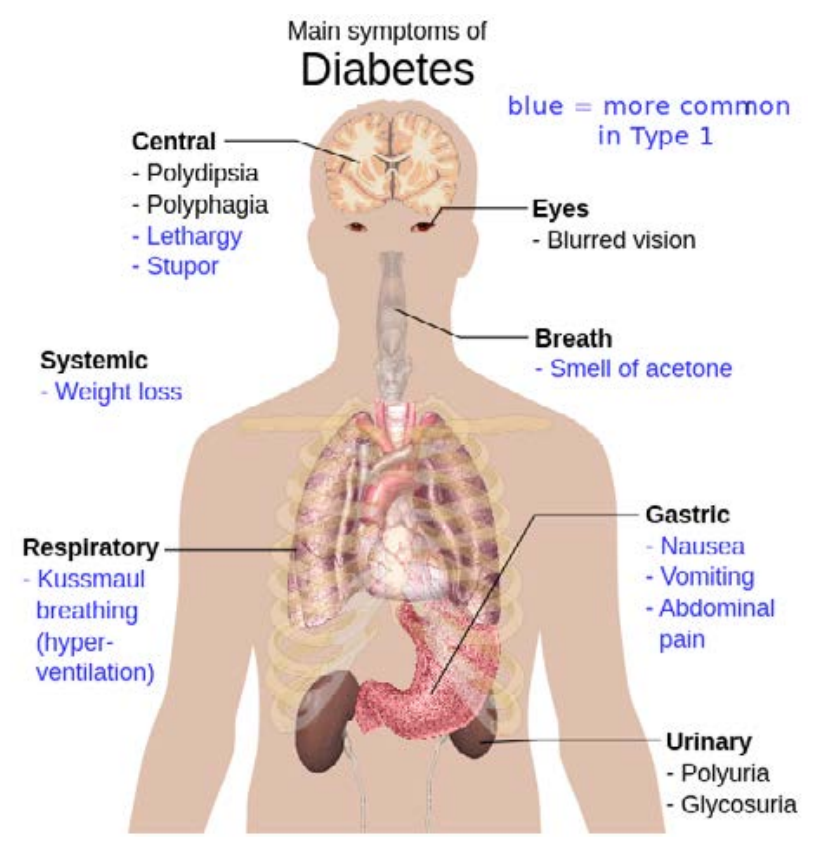

FIGURE 5. Diabetes. From https://commons.wikimedia.org/wiki/ File:Main_symptoms_of_diabetes.svg 
recognition algorithms were applied to discern multiple species of bacteria in vitro. ${ }^{46}$ Other studies with potential applications in medicine investigated biomarkers for Gram-type differentiation of bacteria, ${ }^{47}$ proteomes, ${ }^{48}$ and metabolomes, ${ }^{49-51}$ Medical applications of IMS in breath analysis ${ }^{52}$ and FAIMS applications in medical diagnostics ${ }^{53}$ have been reviewed.

\section{PHARMACEUTICAL APPLICATIONS}

IMS is a fast, low-cost, and sensitive analytical method for quality assessment and control of the production line in the food and pharmaceutical industries, routine screening of batches of raw materials, and the final commercial products. IMS spectra can be obtained in 20-45 ms; IMS instruments can be self-assembled at low cost in the laboratory and maintenance is inexpensive. ${ }^{54}$ IMS has been applied to the quantification of propofol, ${ }^{5}$ detection of cortisone and betamethasone ${ }^{55}$, carbamazepine, ${ }^{56}$ and acetaminophen, aspartame, bisacodyl, caffeine, dextromethorphan, diphenhydramine, famotidine, glucosamine, guaifenesin, loratadine, niacin, phenylephrine, pyridoxine, thiamine, and tetrahydrozoline in over-the-counter-drugs and beverages. ${ }^{57}$ O'Donnell et al. ${ }^{58}$ reviewed the applications of IMS, differential mobility spectrometry, and FAIMS for quality assurance, process monitoring, and maintenance of worker health and safety in the pharmaceutical industry.

IMS represents a low cost, fast and reliable instrumental alternative for the diagnosis of different diseases and metabolic states through the analysis of volatile metabolites found in breath, urine, blood, faeces, and other biological samples. IMS can be used for quality assessment and control in the pharmaceutical industry, and as an alternative to anaesthesia monitoring technologies. Odour analysis in clinical trials is increasing dramatically in a wide range of areas such as several types of cancer, bowel, lung and kidney diseases by sorting through volatile molecules in their breath, sweat, urine, faeces or blood ${ }^{59}$ by means of real-time and low-cost analyses and constitutes a non-invasive diagnostic for the Medicine of the third millennium.

\section{RESUMO}

A espectrometria de mobilidade iônica (IMS) é uma técnica rápida, de baixo custo, portátil e sensível que separa íons em um tubo de deriva sob a influência de um campo elétrico de acordo com seu tamanho e forma. A IMS representa uma alternativa instrumental não invasiva e confiável para o diagnóstico de diferentes doenças por meio da análise de metabólitos voláteis em amostras biológicas. A IMS possui aplicações em medicina no estudo de compostos voláteis para o diagnóstico não invasivo de carcinoma brônquico, doença pulmonar obstrutiva crônica e outras doenças que analisam respiração, urina, sangue, fezes e outras amostras biológicas. A IMS tem sido usada para estudar misturas complexas, como proteomas, metabólitos, organismos completos como bactérias e vírus, monitorar agentes anestésicos, determinar drogas, produtos farmacêuticos e compostos voláteis em fluidos corporais e outros fluidos. As aplicações farmacêuticas incluem análises de medicamentos sem receita, avaliação de qualidade e verificação de limpeza. A prática médica precisa de métodos não invasivos, robustos, seguros, rápidos, em tempo real e de baixo custo com instrumentos de alta sensibilidade e tamanho compacto para diagnosticar diferentes doenças e a IMS é a ferramenta de diagnóstico que atende a todos esses requisitos da medicina do futuro.

PALAVRAS-CHAVE: Espectrometria de mobilidade iônica. Testes respiratórios. Pneumopatias. Carcinoma broncogênico.

\section{REFERENCES}

1. Fernández-Maestre R. Ion mobility spectrometry: history, characteristics and applications. Rev UDCA Actual Divulg Cient. 2012;15(2):467-79.

2. Amann A, Miekisch W, Schubert J, Buszewski B, Ligor T, Jezierski T, et al. Analysis of exhaled breath for disease detection. Annu Rev Anal Chem (Palo Alto Calif). 2014;7:455-82.

3. Vautz W, Nolte J, Fobbe R, Baumbach JI. Breath analysis-performance and potential of ion mobility spectrometry. | Breath Res. 2009;3(3):036004.

4. Hauschild AC, Baumbach JI, Baumbach J. Integrated statistical learning of metabolic ion mobility spectrometry profiles for pulmonary disease identification. Genet Mol Res. 2012;11(3):2733-44.

5. Carstens E, Hirn A, Quintel M, Nolte J, Jünger M, Perl T, et al. On-line determination of serum propofol concentrations by expired air analysis. Int I Ion Mobil Spectrom. 2010;13(1):37-40.

6. Bessa V, Darwiche K, Teschler H, Sommerwerck U, Rabis T, Baumbach Jl, et al. Detection of volatile organic compounds (VOCs) in exhaled breath of patients with chronic obstructive pulmonary disease (COPD) by ion mobility spectrometry. Int J Ion Mobil Spectrom. 2011;14(1):7-13.

7. Finthammer M, Beierle C, Fisseler |, Kern-Isberner G, Baumbach II. Using probabilistic relational learning to support bronchial carcinoma diagnosis based on ion mobility spectrometry International. Int J lon Mobil Spectrom. 2010;13(2):83-93.

8. Pagonas N, Vautz W, Seifert L, Slodzinski R, Jankowski |, Zidek W, et al. Volatile organic compounds in uremia. PLoS One. 2012;7(9):e46258.

9. Arasaradnam RP, McFarlane MJ, Ryan-Fisher C, Westenbrink E, Hodges P, Thomas MG, et al. Detection of colorectal cancer (CRC) by urinary volatile organic compound analysis. PloS One. 2014;9(9):e108750.

10. Westenbrink E, Arasaradnam RP, O'Connell N, Bailey C, Nwokolo C, Bardhan KD, et al. Development and application of a new electronic nose instrument for the detection of colorectal cancer. Biosens Bioelectron. 2015;67:733-8. 
11. Arasaradnam RP, McFarlane M, Daulton E, Westenbrink E, O'Connell N, Wurie $S$, et al. Non-invasive distinction of non-alcoholic fatty liver disease using urinary volatile organic compound analysis: early results. | Gastrointest Liver Dis. 2015;24(2):197-201.

12. Arasaradnam RP, Westenbrink E, McFarlane MJ, Harbord R, Chambers S, O'Connell N, et al. Differentiating coeliac disease from irritable bowel syndrome by urinary volatile organic compound analysis: a pilot study. PloS One. 2014;9(10):e107312.

13. Sagar NM, Cree IA, Covington JA, Arasaradnam RP. The interplay of the gut microbiome, bile acids, and volatile organic compounds. Gastroenterol Res Pract. 2015;2015:398585

14. Cakir $Y$, Métrailler L, Baumbach Jl, Kraus T. Signals in asbestos related diseases in human breath: preliminary results. Int I lon Mobil Spectrom. 2014;17(2):87-94

15. Van Berkel JJ, Dallinga JW, Möller GM, Godschalk RW, Moonen E), Wouters EF, et al. A profile of volatile organic compounds in breath discriminates COPD patients from controls. Respir Med. 2010;104(4):557-63.

16. Bunkowski A, Maddula S, Davies AN, Westhoff M, Litterst $P$, Bodeker $B$, et al. One-year time series of investigations of analytes within human breath using ion mobility spectrometry. Int J Ion Mobil Spectrom. 2010;13(34):141-8.

17. Greulich T, Fischer H, Lubbe D, Nell C, Ingo Baumbach J, Koehler U, et al. Obstructive sleep apnea patients can be identified by ion mobility spectrometry-derived smell prints of different biological materials. J Breath Res. 2018;12(2):026006.

18. Jazan E, Mirzaei H. Direct analysis of human breath ammonia using corona discharge ion mobility spectrometry. | Pharm Biomed Anal. 2014;88:31520.

19. Westhoff M, Litterst P, Freitag $L$, Baumbach JI. Ion mobility spectrometry in the diagnosis of sarcoidosis: results of a feasibility study. J Physiol Pharmacol. 2007;58 Suppl 5(Pt 2):739-51

20. Bunkowski A, Böedeker B, Bader S, Westhoff M, Litterst P, Baumbach JI. MCC/IMS signals in human breath related to sarcoidosis-results of a feasibility study using an automated peak finding procedure. J Breath Res. 2009;3(4):046001.

21. Basanta M, Jarvis RM, Xu Y, Blackburn G, Tal-Singer R, Woodcock A, et al. Non-invasive metabolomic analysis of breath using differential mobility spectrometry in patients with chronic obstructive pulmonary disease and healthy smokers. Analyst. 2010;135(2):315-20.

22. Allers M, Langejuergen J, Gaida A, Holz O, Schuchardt S, Hohlfeld JM, et al. Measurement of exhaled volatile organic compounds from patients with chronic obstructive pulmonary disease (COPD) using closed gas loop GC-IMS and GC-APCI-MS. J Breath Res. 2016;10(2):026004.

23. Bousamra $M 2^{\text {nd }}$, Schumer E, Li M, Knipp RJ, Nantz MH, van Berkel V, et al. Quantitative analysis of exhaled carbonyl compounds distinguishes benign from malignant pulmonary disease. J Thorac Cardiov Surg. 2014;148(3):1074-80

24. Li M, Yang D, Brock G, Knipp Rl, Bousamra M, Nantz MH, et al. Breath carbonyl compounds as biomarkers of lung cancer. Lung Cancer 2015;90(1):92-7.

25. Westhoff M, Litterst P, Freitag L, Urfer W, Bader S, Baumbach JI. Ion mobility spectrometry for the detection of volatile organic compounds in exhaled breath of patients with lung cancer: results of a pilot study. Thorax. 2009;64(9):744-8

26. Castro MDL, Fernandez-Peralbo MA. Analytical methods based on exhaled breath for early detection of lung cancer. TrAC Trend Anal Chem. 2012;38:13-20

27. Zang X, Pérez IJ, Jones CM, Monge ME, McCarty NA, Stecenko AA, et al. Comparison of ambient and atmospheric pressure ion sources for cystic fibrosis exhaled breath condensate ion mobility-mass spectrometry metabolomics. J Am Soc Mass Spectrom. 2017;28(8):1489-96.

28. Schneider T, Hauschild AC, Baumbach II, Baumbach |. An integrative clinical database and diagnostics platform for biomarker identification and analysis in ion mobility spectra of human exhaled air. J Integr Bioinform. 2013;10(2):218.

29. Baker ES, Burnum-Johnson KE, lacobs IM, Diamond DL, Brown RN, Ibrahim YM, et al. Advancing the high throughput identification of liver fibrosis protein signatures using multiplexed ion mobility spectrometry. Mo Cell Proteomics. 2014;13(4):1119-27.

30. Arasaradnam RP, Ouaret N, Thomas MG, Gold P, Quraishi MN, Nwokolo CU, et al. Evaluation of gut bacterial populations using an electronic e-nose and field asymmetric ion mobility spectrometry: further insights into 'fermentonomics'. | Med Eng Technol. 2012;36(7):333-7.
31. Arasaradnam RP, Ouaret N, Thomas MG, Quraishi N, Heatherington E, Nwokolo CU, et al. A novel tool for noninvasive diagnosis and tracking of patients with inflammatory bowel disease. Inflamm Bowel Dis. 2013;19(5):999-1003.

32. Arasaradnam R, Ouaret $N$, Thomas M, Hetherington $E$, Nwokolo CU, Bardhan KD, et al. Identification of inflammatory bowel disease (IBD) using Field Asymmetric lon Mobility Spectrometry (FAIMS). Gastroenterol. 2012;142:S-538.

33. Covington |A, Wedlake L, Andreyev |, Ouaret N, Thomas MG, Nwokolo $\mathrm{CU}$, et al. The detection of patients at risk of gastrointestinal toxicity during pelvic radiotherapy by electronic nose and FAIMS: a pilot study. Sensors (Basel). 2012;12(10):13002-18.

34. Covington IA, Westenbrink EW, Ouaret N, Harbord R, Bailey C, O'Connell $\mathrm{N}$, et al. Application of a novel tool for diagnosing bile acid diarrhoea. Sensors (Basel). 2013;13(9):11899-912.

35. Isailovic D, Plasencia MD, Gaye MM, Stokes ST, Kurulugama RT, Pungpapong $\mathrm{V}$, et al. Delineating diseases by IMS-MS profiling of serum $\mathrm{N}$-linked glycans. J Proteome Res. 2012;11(12):576-85.

36. Isailovic D, Kurulugama RT, Plasencia MD, Stokes ST, Kyselova Z, Goldman R, et al. Profiling of human serum glycans associated with liver cancer and cirrhosis by IMS-MS. J Proteome Res. 2008;7(3):1109-17.

37. Zhang X, Chiu VM, Stoica G, Lungu G, Schenk JO, Hill HH Jr. Metabolic analysis of striatal tissues from Parkinson's disease-like rats by electrospray ionization ion mobility mass spectrometry. Anal Chem. 2014;86:3075-83.

38. Bleiholder C, Do TD, Wu C, Economou NJ, Bernstein SS, Buratto SK, et al. Ion mobility spectrometry reveals the mechanism of amyloid formation of $A \beta(25-35)$ and its modulation by inhibitors at the molecular level: epigallocatechin gallate and scyllo-inositol. | Am Chem Soc. 2013;135(45):1692637.

39. Woods LA, Radford SE, Ashcroft AE. Advances in ion mobility spectrometry-mass spectrometry reveal key insights into amyloid assembly. Biochim Biophys Acta. 2013;1834(6):1257-68.

40. Bocos-Bintintan V, Moll VH, Flanagan RI, Thomas CLP. Rapid determination of alcohols in human saliva by gas chromatography differential mobility spectrometry following selective membrane extraction. Int | lon Mobil Spectrom. 2010;13(2):55-63.

41. Eiceman GA, Shoff DB, Harden CS, Snyder AP, Martinez PM, Fleischer $M E$, et al. Ion mobility spectrometry of halothane, enflurane, and isoflurane anesthetics in air and respired gases. Anal Chem. 1989;61(10):1093-9.

42. Galassetti PR. Novak B, Nemet D, Rose-Gottron C, Cooper DM, Meinardi $S$, et al. Breath ethanol and acetone as indicators of serum glucose levels: an initial report. Diabetes Technol Ther. 2005;7(1):115-23.

43. Smith $D$, Spaněl $P$, Fryer AA, Hanna F, Ferns GA. Can volatile compounds in exhaled breath be used to monitor control in diabetes mellitus? | Breath Res. 2011;5(2):022001

44. Wang Z, Wang C. Is breath acetone a biomarker of diabetes? A historical review on breath acetone measurements. J Breath Res. 2013;7(3):037109.

45. Snyder AP, Shoff DB, Eiceman GA, Blyth DA, Parsons JA. Detection of bacteria by ion mobility spectrometry. Anal Chem. 1991;63(5):526-9.

46. Shnayderman M, Mansfield B, Yip P, Clark HA, Krebs MD, Cohen SI, et al. Species-specific bacteria identification using differential mobility spectrometry and bioinformatics pattern recognition. Anal Chem. 2005;77(18):5930-7.

47. Dworzanski JP, Tripathi A, Snyder AP, Maswdeh WM, Wick CH. Novel biomarkers for Gram-type differentiation of bacteria by pyrolysis-gas chromatography-mass spectrometry. J Anal Appl Pyrol. 2005;73(1):29-38.

48. Zhong Y, Hyung S|, Ruotolo BT. Ion mobility-mass spectrometry for structural proteomics. Expert Rev Proteomics. 2012;9(1):47-58.

49. Dwivedi P, Puzon G, Tam M, Langlais D, Jackson S, Kaplan K, et al. Metabolic profiling of Escherichia coli by ion mobility-mass spectrometry with MALDI ion source. | Mass Spectrom. 2010;45(12):1383-93.

50. Dwivedi P, Schultz A), Hill HH. Metabolic profiling of human blood by high-resolution ion mobility mass spectrometry (IM-MS). Int I Mass Spectrom. 2010;298(1-3):78-90.

51. Tebani A, Schmitz-Afonso I, Rutledge DN, Gonzalez BJ, Bekri S, Afonso C. Optimization of a liquid chromatography ion mobility-mass spectrometry method for untargeted metabolomics using experimental design and multivariate data analysis. Anal Chim Acta. 2016;913:55-62.

52. Vautz W, Baumbach II, Westhoff M, Züchner K, Carstens ETH, Perl T. Breath sampling control for medical application. Int J lon Mobil Spectrom. 2010;13(1):41-6.

53. Covington |A, van der Schee MP, Edge AS, Boyle B, Savage RS, Arasarad- 
nam RP. The application of FAIMS gas analysis in medical diagnostics. Analyst. 2015;140(20):6775-81.

54. Tan Y, DeBono R. IMS for drugmaking: Ion mobility spectrometry can improve pharmaceutical companies' production efficiency. Today's Chemist at Work 2004; November:15-6. Available from: http://vertassets.blob. core.windows.net/download/737377cc/737377cc-a83f-4dcc-9a3572dfb745d321/ims.pdf

55. Fernández-Maestre R. Reduced ion mobilities of aspartame, cortisone, betamethasone, butylparaben, propylparaben and vanillin. Int J lon Mobil Spectrom. 2017;20(1-2):11-3.

56. Kalhor H, Hashemipour S, Yaftian MR, Shahdousti P. Determination of carbamazepine in formulation samples using dispersive liquid-liquid microextraction method followed by ion mobility spectrometry. Int J lon Mobil Spectrom. 2016;19(1):51-6.

57. Fernández-Maestre R, Hill HH. Ion mobility spectrometry for the rapid analysis of over-the-counter drugs and beverages. Int J lon Mobil Spectrom. 2009;12(3):91-102.

58. O'Donnell RM, Sun $X$, Harrington PB. Pharmaceutical applications of ion mobility spectrometry. TrAC Trends Anal Chem. 2008;27(1):44-53.

59. Murphy K. One day, a machine will smell whether you're sick. Owlstone Medical's. [Accessed December 1, 2017]. Available from: https:// www.owlstonemedical.com/about/news/2017/may/2/one-daymachine-will-smell-whether-youre-sick-new-/ 